\title{
Skin abnormality and hairloss: the reproductive endocrinological viewpoint
}

\author{
Ali Baziad
}

\begin{abstract}
Abstrak
Produksi androgen yang berlebihan menyebabkan terjadinya perubahan pada kulit wanita berupa hirsutisme dan akne. Pemberian hormon antiandrogen seperti siproteron asetat dapat menghilangkan dampak kelebihan androgen terhadap kulit. Kerontokan rambut juga dapat disebabkan oleh hormon androgen yang tinggi dan kadar estrogen yang rendah. Pemberian hormon antiandrogen dan pemberian hormon estrogen dapat mengurangi kerontokan rambut. Virilisasi yang meliputi pertumbuhan rambut lebat, pembesaran klitoris, perubahan suara, hipertrofi otot dan hipoplasia payudara juga disebabkan oleh hiperandrogenemia dan pemberian antiandrogen dapat menghilangkan dampak virilisasi. Sebaliknya, kekurangan hormon androgen berkaitan dengan timbulnya selulit, sedangkan testosteron topikal dapat menghilangkan selulit. Disimpulkan bahwa abnormalitas kulit dan atau kerontokan rambut berhubungan dengan pemberian hormon androgen pada wanita. Pengobatan dengan hormon antiandrogen dapat mengurangi atau menyembuhkan kelainan tersebut. (Med J Indones 2004; 13: 258-63)
\end{abstract}

\begin{abstract}
Excessive androgen production may cause changes in female skin, such as hirsutism and acne. The administration of antiadrogenic hormone such as cyproteron acetate, may eliminate the hyperandrogenic effect on the skin. Hairloss may also caused either by hyperandrogenemia or by low estrogen level. The administration of either antiandrogen or estrogen may reduce hairloss. Virilization, which includes excessive growth of hair and clitoris enlargement, deepened voice, muscle hypertrophy and mammary hypoplasia are also associated with hyperandrogenemia. Antiandrogen treatment could eliminate these impacts of virilization. In contrast, cellulite was supected to be due to androgen deficiency, and the use of topical testosterone could eliminate it. It is concluded that skin and/or hairloss are associated with hormonal changes in women. The treatment with antiandrogenic hormones may reduce or cure these abnormalities. (Med J Indones 2004; 13: 258-63)
\end{abstract}

Keywords: Hirsutism, virilization, acne, cellulite, hairloss, androgen, estrogen

Excessive androgen production may result in androgenization on female skin, such as hair growth in unusual sites. This hair growth may sometimes thick enough and disturbing. In addition, as a result of high serum androgen level (hyperandrogenemia), acne and oily facial skin may appear. The excessive hair growth is known as hirsutism. The most affected sites of female body are lips, chin, chest, linea alba, and the inner side of thigh. Hirsutism should be differentiated from hypertrichosis in which the excessive hair growth is not due to excessive androgen, but to other diseases. ${ }^{1}$

Department of Obstetrics and Gynecology, Faculty of Medicine, University of Indonesia/Dr. Cipto Mangunkusumo Hospital, Jakarta, Indonesia
Hyperandrogenemia not only enhances hair mitosis, but also triggers the sebum formation. Therefore excessive androgen can also cause hairloss. The most affected areas are temporal and mentoparietal areas. Estrogen deficiency may also cause hairloss, as commonly encountered in menopausal women.

Beside hirsutism and hypertrichosis, hyperandrogenemia can also cause virilization. Which includes exessive growth of hair, clitoromegaly, deepened voice, muscle hypertrophy, reduced subcutaneous fat and mammary hypoplasia. ${ }^{1,2}$ Virilization encountered in hyperandrogenemia reflects severe endocrinological abnormality, typically originating from ovarian or adrenal tumors.

The impact of hyperandrogenemic states can be treated with antiandrogenic drugs. One of them is cy- 
proterone acetate, which is at present available in Indonesia as contraceptive pill (Diane 35). ${ }^{3}$ Hyperandrogenemia can also be treated with combined contraceptive pill containing high estrogen level. ${ }^{4}$ Estrogen induces the SHBG (serum human binding globulin) formation in the liver, increasing the bound of androgen in the serum.

When the hairloss is caused by estrogen deficiency, the treatment of choice is hormone replacement therapy by means of tablet, cream, or hair oil.

In this paper, clinical aspects, as well as the treatments of some skin and hair abnormalities will be elaborated.

\section{HIRSUTISM}

Hirsutism is the excessive growth of hair which generally due to hyper androgenemia. The androgen is produced by two important organs, i.e. ovaries and suprarenal gland. Any disorder of these organs (tumor, cancer), may manifest in hyperandrogenemia. ${ }^{5}$ Hyperandrogenemia may also be found in several pathologic conditions such as : Adrenogenital syndrome, Cushing syndrome, Acromegaly, Intersexuality, Anabolics, androgenic drugs such as, corticosteroid, ACTH, diphenylhydantoin, etc.

However, approximately $90 \%$ of hyperandrogenemia is idiophatic.

Hirsutism is classified as follows:

1. Mild hirsutism; mild hair growth, but creating cosmetical concern for the subject,

2. Moderate hirsutism; hair growth becomes apparent in certain areas,

3. Severe hirsutism; severe hair growth in all areas.

Androgen produced by certain disordered organs, mainly ovaries and adrenal glands will be changed from inactive to its active from in the skin. In the serum most of the androgen is bound to SHBG, remaining free androgen level up to only 1-2\%. Low SHBG level as occurred in hepatic disorder will increase free androgen level. Hair follicles and skin are able to change testosterone from inactive form to its active i.e. 5-alfa dehydrotestosterone (DHT).

\section{Diagnosis problem in hirsutism}

Hormonal analysis is necessary for diagnostic purpose in hirsutism. Testosterone and dehydroepiandrosteron sulfate (DHEAS) are two main hormones associated with hirsutism. Testosteron is primarily produced by the ovaries while DHEAS is primarily produced by adrenal glan. Blood sample is taken at the early follicular phase, between 8 a.m. and 10 a.m. To exclude the ovarian adrenal tumor, USG or MRI should be undertaken. Since ovaries and adrenal gland can produce androgen, ovarian and suprarenal tumor should be suspected if :

1. High Testosterone level $(>1.0 \mathrm{ng} / \mathrm{ml})$

2. Abnormal DHEAS level $(>7000 \mathrm{ng} / \mathrm{ml})$

3. Hair growth steadily continues after a periodic observation

4. Virilization condition is apparent

5. Menstrual disorder

6. No response to antiandrogen after $>1$ year of treatment

There is also a simple method to identify the existence of ovarian or adrenal tumor by inhibition test using combined contraceptive pill for one month, followed by measuring the serum testosterone. If the level decreases, it is higly suggestive of the absence of tumor. But if the level remains high, it means that the function can not be influenced indicating that ovarian tumor is autonomous. Other methode to identify ovarian and adrenal tumor is by inhibition test using dexamethasone.

Hair cells and sebaceous glands, contain 5-alfa reductase enzyme. ${ }^{2}$ Detection of the activity of this enzyme is performed by examining the 13 alpha- 17 beta androstandiol glucoronide which represents enzyme marker. It is possible that the level of serum androgen is normal, but the level of enzyme marker is high. This phenomen reflects the acvitity of 5-alfa reductase enzyme in hair follicles and sebaceous glands.

\section{Medical treatment of hirsutism}

Progestogen cyproterone acetate (CPA) or chlormadinon is a simple therapy for hirsutism. Both types of progestogen possess antiandrogenic effect. ${ }^{3,4} \mathrm{Com}-$ bined contraceptive pills containing siproteron acetate (Diane 35) are now available. CPA occupies competitively the androgen receptor, while ethynil estradiol induces SHBG synthesis in the liver, resulting in more 
testosterone bound in the serum. CPA may also inhibit the activity of 5-alfa reductase enzyme, by changing testosterone from inactive to active form.

Conventional contraceptive pills can also be used to treat androgenization in women, but pill containing progestogen having a weak androgenic effect is prefered. ${ }^{7}$

High-dose CPA is use for severe hirsutism. For example, $100 \mathrm{mg}$ of CPA from day 5 to day 14 of the menstrual cycle, added with $40 \mu \mathrm{g}$ of ethynil estradiol from day 5 to day 25 of the menstrual cycle. If hirsutism is still exist, an intra muscular depo injection 300 $\mathrm{mg}$ of CPA once a month can be given. ${ }^{8}$ The high dose CPA, should not be used longer than one year period. During the treatment, the patient are not allowed to be pregnant.

Low-dose CPA is sufficient for mild hirsutism, such as available in combined contraceptive pill (Diane 35 ), which is allowed to be used for 10-12 months.

The side effects of CPA include fatiguability, reduced libido, increased body weight, breast pain, nausea, and menstrual disorder. This lead to low patient compliance. $^{3,9}$

Spironolactone has been used for the treatment of hyperandrogenism; but, today it has been gradualy abandoned. While occupying androgen receptor, it can also inhibit 5-alfa reductase enzyme present in the skin. Spironolactone is available as ointment and can be applied twice daily on the hair growing area. ${ }^{2}$ This application does not result in hairloss but inhibit its growth. This drug can also be taken orally with daily dosage of 50-100 mg.

\section{ACNE}

Acne is one of the clinical manifestation of hiperandrogenemia. Testosteron is able to stimulate sebaceous gland in the skin producing oily hair and skin. However the presence of acne may also indicates the onset of puberty, and that the ovaries start their function. Acne in some adolescents may create psychological disturbances. They shy away from getting along with their peers, and may loss of self-confidence. The exact etiology of acne is not yet completely revealed. It is believed that genetic factors play an important role. It is generally accepted that acne is associated with disruption of female hormonal system. ${ }^{2}$
For the purpose of therapy, acne is divided into four degrees, i.e:

1. Degree 1 . Very mild ance, appear shortly before menstruation and disappear there after

2. Degree 2. Mild acne, found on only a part of the face.

3. Degree 3. Moderate acne, found on more than half parts of the face, as well as on the back and other parts of the body.

4. Degree 4. Severe acne. Almost all parts of the face are covered by acne, and some are found subcutaneously and secretes fat.

Dihydrostestoterone does not only stimulates the activitiy of sebaceous gland, but also the formation of skin collagen. This results in thickening of skin layer and occlusion of skin excretion. The sebum is produced continuously, but since its excretion is occluded, the bacteria grows easily. Certain types of bacteria dissociate the fats into smaller parts. These fats may iritate the tissues, causing inflammation, followed by infection, resulting in the formation of acne. Interestingly acne present only in certain areas with high activity of 5-alfa reductase enzyme.

Unfortunalety, several combined contraceptive pills may cause acne, particularly those containing progestogen such as nortestosterone derivative. Acne may profusely appear in women within stress situation, such as before exam. Medication with corticosteroid, barbiturate, cyclosporine, and bromin may also cause acne or aggravate the pre existing acne. ${ }^{2}$ Depression is a poison for the skin, because subcutaneous blood flow decreases as a result of the constriction of skin vessels. Psychologists believe that guilty, anger, and loss of self-confidence may increase sebum production and facilitate acne formation. Thus, it generally said that changes in the skin may show individual personality.

\section{Hormone treatment of acne}

When hyperandrogenemia has been ascertained as the cause of acne, anti-androgenic drug is then the treatment of choice. Treatment with certain combined contraceptive pills may suppress ovarian functions, allow the ovaries to cease producing androgen and makes the skin looked more beautiful. This represents the evident that contraceptive pills do not always have negative effect, but also have positive effects. Similar hormonal therapy may also be applied for acne and 
hirsutism. Estrogen may inhibit the sebum production, allowing it to be used for treating acne. It is preferable to administer estrogen salve.

\section{HAIRLOSS}

Hairloss in women may be caused by numerous factors, but hormonal factor is thought to be the most frequently cause estrogen deficiency and excessive androgen may be associated with hairloss. It is evident in daily practice that many women experiencing hairloss come to gynecologist to seek help. In fact, normal serum hormonal level does not always mean that tissu hormonal level is also normal. It is possible, that androgen or estrogen in the serum is normal, while its level in hair follicles is high. Hairloss is also influenced by hormone and vitamin D3. ${ }^{10}$ Beside hormonal factor, hairloss may also be considered related to immunological process, because there is a functional relationship between immunology and sex steroid.

Hair follicles stimulated the formation of growth factor, IGF-1, and also accelerate hair growth by enhancing the mitotic process at $S$ phase of cell cycle. It has been proven that 17 beta estradiol can occupy gene receptor of IL-6. ${ }^{10}$ Stress causes secretion of IL-6 cytokine, which function as inflammatory mediator resulting in hairloss. Stress and changes in psychological mood may also cause hairloss. It is not uncommon that women with sexual disturbances complain of hairloss.

During post-delivery and post-menopausal period, where estrogen level is low, women frequently experience hairloss. In addition, in women using combined contraceptive pills hairloss is also frequently encountered. Contraceptive pills containing synthetic estrogen of ethynil estradiol suppress ovarian function. This result is inhibition of follicle growth and decreased estrogen production. 17-beta estradiol is the most important estrogen for hair growth. Moreover, during the use of contraceptive pills follic acid and vitamin B12 level decreases, while they play a significant role in hair growth. Infact not all women using contraceptive pills suffer from hairloss. It is interesting to note that in certain group of women, the combined contraceptive pills can stimulate hair growth.

\section{Diagnotic problem in hairloss}

In a patient complaining of hairloss, microscopic hair examination or macroscopic examination of scalp tissue specimen may clarify diagnosis. Localization of bold area of the scalp may suggest that the hairloss is associated with hormonal abnormality. Family history of having similar type of hairloss is necessary to identity. A positive history may lead to a genetic factor. If the hairloss has started from puberty, hormonal insufficiency is the most suggestive factor. Eventhough, post-delivery and post-menopausal hairloss are also closely associated with the hormonal changes.

Hormonal analysis may be useful to identify the cause of hairloss. However, a normal hormonal result does not always able to exclude hormonal abnormality, since the hair follicles have the ability to change testosterone from inactive to its active form, i.e. dyhidrotestosterone (DHT), maintaining its high level in hair follicles. ${ }^{11}$ High prolactin level (hyperprolactinemia) may also cause hairloss, therefore exploration toward the cause of hyperprolactinemia is also necessary. ${ }^{10}$ Anemia, magnesium, and zinc deficiency may play role as causative factor of hairloss.

\section{Hormonal treatment of hairloss}

Healthy lifestyle may combat the diseases, including those affecting hair. Certain chemical substances may damage hair. Excessive hair washing, and exessive use of hair dryer will farow hairloss since it increase fat secretion and sebum production. ${ }^{2}$

Short haircut is preferred to prevent hairloss, because it stimulates regeneration phase of hair growth, and facilitates profuse hair growth.

Several weeks after childbirth, a physiological recovery occurs during which the process of hairloss ceases by itself. Despite estrogen level is low, estrogen therapy is not allowed for post-delivery women because it can stop breastmilk production. However, cream or hair oil containing estrogen can be used if hairloss still continues after childbirth. ${ }^{2,1}$ Estrogenic cream or estrogenic hair oil generally contains estriol (E3), a weak estrogen, which does not elicit systemic effect. Once a day administration is considered effective to stimulate hair growth.

Combined contraceptive pills users frequently complained of hairloss. A simple method to identify whether the hairloss is caused by pills or not, is by stopping to use pills temporarely for several months. Improvement of hair growth suggests the role of the pills in hair loss. However, withdrawal of pills may 
risk pregnancy. Therefore, instead of stopping pills it might be sufficient to add topical estriol (E3) vitamin B6 and follic acid, but this only needed if hairloss persists.

During climacteric period, hairloss may be due to estrogen deficiency, which can be treated with hormone replacement therapy (HRT). In women with intact uterus, estrogen should always be combined with progestogen in order to prevent endometrial cancer. However, testosterone-derived progestogen is not preferred, because high androgen level may result in hairloss. Progesterone-derived progestogen, such as normogestrol acetate (Lutenyl), or medroxyprogesterone acetate (Prothyra) is preferable. Patient refusing to use oral hormone replacement therapy is advised to use E2 cream or topical estriol (E3). Topical estriol may be combined with Minoxidil which triggers hair sprout to grow, while estriol triggers the hair sprout to keep growing. ${ }^{2}$

During puberty, the production of aromatase enzyme increases. This enzyme converts androgen into estrogen. Therefore despite high androgen level within hair follicles is does not inhibit hair growth. Impairment in aromatase enzyme activity may disturb conversion of androgen into estrogen, leading to increase of androgen which further produce hairloss. This phenomenon is frequently seen in women treated with drugs impairing aromatase enzyme activity which are commonly used for breast cancer and adenomyosis.

In hair follicles, the testosterone is transformed by 5alfa reductase enzyme from inactive into its active form, i.e. dyhidrotestosterone (DHT). The action of scalp DHT differs from that in other skin areas of the body. In scalp, DHT induces conversion of terminal hair into lanugo, while in another areas, DHT converts lanugo into terminal hair. Currently, two isoforms of 5-alfa reductase enzyme have been identified. ${ }^{10}$ Isoform-2 is responsible for hair, while isoform-1 is responsible for conversion of testosterone into DHT. Finasterid, is a drug which can inhibit 5-alfa reductase enzyme in prostate. ${ }^{5}$ Since isoform-1 is also discovered in scalp, it might be a rational reason to use hair oil containing combination of finasterid and estriol (E3).

If high testosterone level is suspected to be the cause of hairloss, antiandrogenic drug such as cyproterone acetate (CPA) may be administered, usually in sequential varied doses, i.e. $2 \mathrm{mg}, 10 \mathrm{mg}, 50$, and 100 $\mathrm{mg}$. Combined contraceptive pill containing $2 \mathrm{mg}$ of CPA with $35 \mu \mathrm{g}$ of ethynile stradiol, as available in
Diane 35 is the most simple choice. If necessary, this contraceptive pill can also be combined with 10-100 mg of SPA for 15 days each month. Topical CPA may also be used, and if the result is not satisfactory, a combined CPA with topical finasterid may be attempted.

Both hyperthyroidism and hypothyroidism may cause hairloss. In women with hypothyroidism, SHBG level decreases, causing increase of serum free testosterone level. However no hairloss is found in hypothyroidism women both in pubic hair and eyelashes.

Vitamin D3 receptor has been discovered in hair follicles. ${ }^{10}$ Vitamin D3 induces not only skin basal cells, but also hair growth. Vitamin D3 deficiency causes slowing of hair growth and make hair easily broken. Vitamin D3 deficiency can be diagnosed by measuring its metabolite 25 hydroxycholecal-ciferol in serum. A level below $30 \mathrm{nmol} / \mathrm{L}$ suggests hypovitaminosis. This condition can be treated with vitamin D3 at a dosage of $1000 \mathrm{IU} /$ perday.

Mild type hairloss found in certain areas on the scalp (coin-shaped baldness), most likely has an immunological etiology. ${ }^{2,10}$ Histologically, lymphochytes infiltration is found in hair follicles. Because estrogen, such as estradiol, (E2), has suppressive effect on immunological process, the systemic or topical estradiol can also be administered.

\section{CELLULITE}

Cellulite is frequently found in women, but rarely in men, except, in castrated men. In the past, cellulite was viewed as a sign of femininity. It is commonly manifested like orange skin. The most frequent sites are inner side of the thigh, and the buttock. The cellulite can be tested by squeezing the thigh skin between two hands, followed by tightly stetching downwards. A positive test will show the skin appears like orange's skin. The cellulite can be also observed by shiftly extending the thigh muscle while sitting on a chair. The worst condition is when cellulite is visible form distant site, either in sitting or standing position.

The exact cause remains unknown, but the role of genetic factor is suspected. Cellulite is more frequently encountered in obese women. ${ }^{2}$ Obesity may aggravate the appearance of cellulite but not considered as the cause. Decreasing low body weight, low fat and fiber-rich diet may reduce cellulite, but cannot heal it. In pregnant women in which their sex steroid 
hormone is high, cellulite is commonly seen. However, during climacteric period in which sex steroid hormone is low, cellulite is also frequently appeared. This is due to low collagen content of the skin during climacteric period.

\section{Hormonal treatment of cellulite}

Topical ointment containing 3\% testosterone has long been used for therapy of cellulite. In addition to eliminating pain, therapy of this sort may result in skin thickening. But, long term administration may cause masculinization. Great care should be taken in administering testosterone for female singer or radio broadcaster, because testosterone may cause change in female's voice. Long-term administration may also result in the disorder of lipid metabolism, which eventually increases the risk of coronary heart disease.

\section{CONCLUSIONS}

Hirsutism and acne and hairloss, is frequently associated with excessive androgen production. But hairloss itself is also caused by low estrogen level. Excessive production of androgen can also cause virilization. The administration of cyproterone acetate (CPA) may eliminate the hyperandrogen effect on the skin. CPA, right now is available in Indonesia as contraceptive pill with brandname Diane 35 . The administration of either CPA or estrogen may reduced hairloss. Cellulite is suspected to be due to androgen deficiency.
The use of topical testosterone could eliminated cellulite.

\section{REFERENCES}

1. Schmidt M. Gynäkologie und Geburtshife. Stuttgart, New York. FK Schattauer Verlag, 1982: 102-8.

2. Huber J. Hormone fur die Schönheit. Genf/München. Ariston Verlag, 1993: 109-23.

3. Hammerstein J, Cupceancu JB. Die Behandlung des Hirsutimus mit Cyproteron acetat. Deutsh Med Wscht 1969;94:829-83.

4. Taubert HD, Kuhl H. Therapeutiche Indikationen für ovulationshemmer. In: Kontrazeption mit Hormonen. Stuttgart-New York.Georg Thieme Verlag., 1995: 219-25.

5. Speroff L, Glass RH, Kase NG. Clinical Gynekology Endocrinology and Infertility. Lippencott Williams \& Wilkins 1999: 523-25.

6. Taubert HD, Derics Tan, JSE. The ovary-suppresion test in the evaluation of hyperandrogenemia. Gynecol Endocrinol 1990;4:109-18.

7. Porcile A, Gallardo E. Oral contraceptive containing desogestrel in the maintenance of remission of hirsutism: monthly versus bimonthly treatment. Contraception 1991;44: 533-40.

8. Marcondes JAW, Wajchenberg BL, Abujamra AC, Luthold WW, Samojlik E, Kirschner MA. Monthly cyproterone acetate in the treatment of hirsute women: clinical and laboratory effects. Fertil Steril 1990;53:40-44.

9. Hammerstein J. Arbeitskreis Antiandrogene. Arch Gynak 1973;214: 243-47.

10. Huber J. Endokrine Gynäkologie. Wien-München-Bern. Verlag Wihelm Maudrich. 1999: 407-8.

11. Horton R. Dehydrotestosterone is a peripheral paracrine hormone. J Androl 1992;13: 23. 